\title{
The Digital Economy and Digital Business
}

\subsection{INTRODUCTION}

Small and rural communities face greater challenges than metropolitan areas in generating economic growth. In addition to access to physical and industrial resources and global market competition, rural communities face further obstacles due to their distance from urban centres, low population levels, and associated low population density (OECD, 2014; Liu, 2021). These factors result in significant differences in the attributes of rural economies compared to urban areas; with rural communities characterised by employment in services and manufacturing (often limited to consumer and basic producer services, and either small scale and/or relatively unsophisticated manufacturing), low skilled and ageing workforces, and low levels of innovation and productivity (OECD, 2014; Liu, 2021). In some areas, these factors are exacerbated by geographic impediments such as unfavourable climate and topographies (Freshwater, 2018). While small and medium-sized enterprises (SMEs) represent approximately $90 \%$ of businesses and more than $50 \%$ of employment worldwide (World Bank, 2021 ), in rural areas, the vast majority of firms are SMEs or, more precisely, micro-enterprises (i.e., firms with less than ten employees). These companies are traditionally reliant on external markets for their growth but at the same time face greater challenges than their urban counterparts such as more limited access to finance, labour shortages, and higher transport costs to external markets (Freshwater et al., 2019). 
Digital technologies present rural enterprises with the opportunity to overcome the constraints of their location. The commercial benefits generated by these technologies such as websites, e-commerce, digital marketing and advertising, and social media for enterprises in general, and for SMEs in particular, are clear and have been documented by a large number of studies (see, for example, Walczuch et al., 2000; Mehrtens et al., 2001; Jones et al., 2003; Claffey \& Brady, 2014; Tiago \& Verissimo, 2014; Jeansson et al., 2017). However, recent research suggests that there exists a digital divide between urban SMEs and rural SMEs in terms of adoption of digital technologies and digital business practices (Richmond et al., 2017). Furthermore, micro-enterprises are often under-represented in official statistics (see, for example, Digital Economy Skills Unit, 2020) therefore making it difficult for policymakers to make informed and effective decisions to close the digital divide in rural communities by both enterprises and individuals. At the same time, the OECD, amongst others, believe that rural areas should drive their own economic development rather than rely on national government, specifically with respect to identifying and mobilising assets to improve economic performance (OECD, 2014). This being in the case, more local and granular data and indicators are needed to guide such local bottom up strategies.

The remainder of this chapter defines the digital economy and digital business and discusses the differences between the two. This is followed by a discussion of the benefits and challenges in adoption and use of digital technologies by enterprises, with an emphasis on SMEs and rural SMEs. The chapter concludes with a discussion of international frameworks and composite indices for measuring the evolution and development of digital technology adoption and use by businesses.

\subsection{What Is the Digital Economy?}

The digital economy, as a phenomenon, is relatively recent, particularly in developing countries and rural areas (World Economic Forum, 2015) even though the technological underpinnings of the digital economy started to be laid out in the 1990s with the initial adoption of enterprise computing and computerised manufacturing (Sturgeon, 2021). The advent of the Internet in the early 2000s represented a stepping stone toward the digital economy as we know it today. The widespread organisational adoption of the Internet has enabled the development and adoption of a number of technologies and services that are at the core of the digital economy. A number of definitions of digital economy have been proposed over time. However, as Bukht and Heeks (2017, p. 4) put it, "definitions are always a 
reflection of the times and trends from which they emerge" and therefore need to adapt as the technological landscape and users' sophistication and knowledge evolve. Table 4.1 provides an overview of how the definition of digital economy has evolved since the early 2000s.

Table 4.1 Selected definitions of digital economy (adapted from Bukht and Heeks, 2017)

Source Definition

Brynjolfsson and Kahin (2000, p. 2)

Kling and Lamb (2000, p. 297)

$\operatorname{OECD}(2013$, p. 1)

Department of

Broadband, Communications and the Digital Economy (2013, p. 128)

European Commission (2013, p. 2)

House of Commons (2016, p. 4)

G20 Digital Economy Task Force (2016, p. 1)

Knickrehm et al. (2016, p. 2)

Dahlman et al. (2016, p. 11)
"[...] the recent and largely unrealised transformation of all sectors of the economy by the computer-enabled digitisation of information".

"[...] includes goods or services whose development, production, sale, or provision is critically dependent upon digital technologies".

"The digital economy enables and executes the trade of goods and services through electronic commerce on the internet". "The global network of economic and social activities that are enabled by digital technology, such as the internet and mobile networks".

"[...] an economy based on digital technologies (sometimes called the internet economy)".

"The digital economy refers to both the digital access of goods and services, and the use of digital technology to help businesses".

"[...] a broad range of economic activities that include using digitised information and knowledge as the key factor of production, modern information networks as an important activity space, and the effective use of information and communication technology (ICT) as an important driver of productivity growth and economic structural optimisation". "The digital economy is the share of total economic output derived from a number of broad 'digital' inputs. These digital inputs include digital skills, digital equipment $[\ldots]$ and the intermediate digital goods and services used in production. Such broad measures reflect the foundations of the digital economy".

The digital economy is the amalgamation of several general purpose technologies $[\ldots]$ and the range of economic and social activities carried out by people over the internet and related technologies. It encompasses the physical infrastructure that digital technologies are based on (broadband lines, routers), the devices that are used for access (computers, smartphones), the applications they power (Google, salesforce) and the functionality they provide (IoT, data analytics cloud computing)". 
Table 4.1 (continued)

\begin{tabular}{ll}
\hline Source & Definition \\
\hline Pratt (2017) & $\begin{array}{l}\text { "The digital economy is the worldwide network of economic } \\
\text { activities enabled by information and communication } \\
\text { technologies (ICT). It can also be defined more simply as an } \\
\text { economy based on digital technologies". } \\
\text { "[..] that part of the economic output derived solely or } \\
\text { primarily from digital technologies with a business model based } \\
\text { on digital goods or services". } \\
\text { "[the] digital economy is characterised by connectivity between } \\
\text { Bukht and Heeks } \\
\text { users and between devices, as well as the convergence of } \\
\text { formerly distinct parts of communication ecosystems such as } \\
\text { fixed and wireless networks, voice and data, and } \\
\text { Telecommunications and broadcasting". }\end{array}$ \\
&
\end{tabular}

As can be seen from Table 4.1, extant definitions of the digital economy vary significantly in terms of scope highlighting a clear lack of agreement around what should be included in or excluded from the digital economy. The G20 Digital Economy Task Force has been active in proposing a common definition for the digital economy, reviewing and proposing new measurement frameworks and composite indicators for the digital economy. For the G20 Digital Economy Task Force (2020, p. 114), the digital economy is defined as:

All economic activity reliant on, or significantly enhanced by the use of digital inputs, including digital technologies, digital infrastructure, digital services and data. It refers to all producers and consumers, including government, that are utilising these digital inputs in their economic activities.

This definition was designed to allow for a flexible approach to measurement including top down and bottom up approaches. Echoing Bukht and Heeks (2017), it allows for a flexible and gradated definition of the digital economy across three tiers (Fig. 4.1):

1. The core measure of the digital economy-economic activity from producers of ICT goods and ICT information services.

2. The narrow measure of the digital economy - the core sector plus economic activity derived from firms that are reliant on digital inputs. 


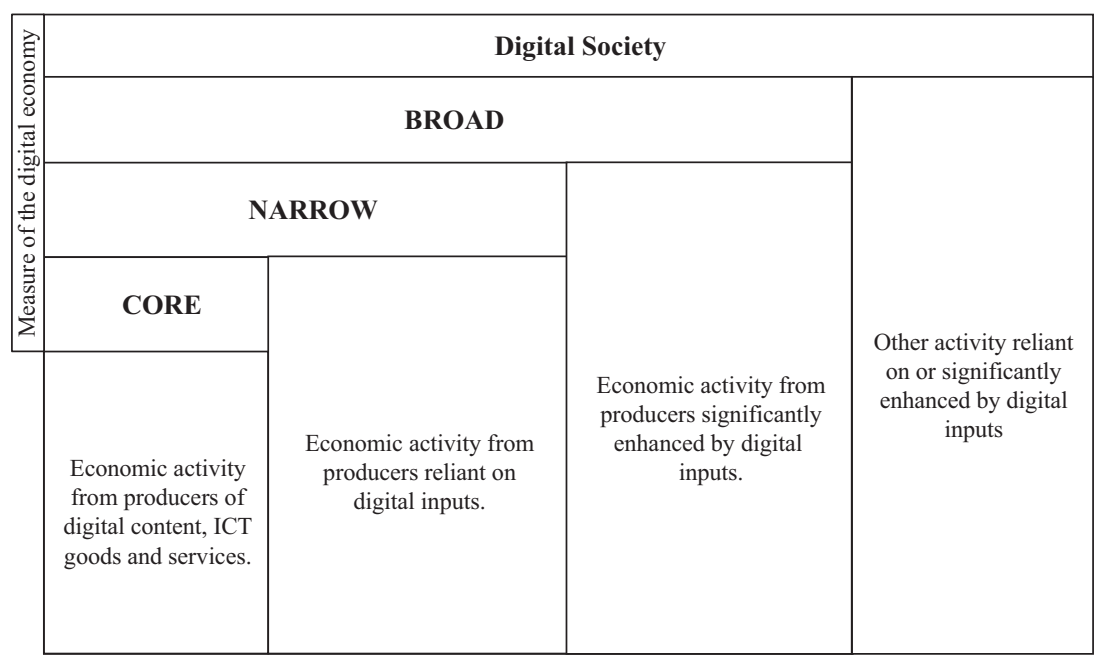

Fig. 4.1 Tiered definition of the digital economy. (Adapted from G20 Digital Economy Task Force, 2020)

3. The broad measure of the digital economy - the first two measures plus economic activity from firms significantly enhanced by the use of inputs.

Furthermore, the G20 Digital Economy Task Force recognise that other parts of the digital society perform digital interactions and activities that add value and impact the economy, which while not strictly part of a digital economy, are important for economic and regional development policies, amongst others (G20 Digital Economy Task Force, 2020).

\subsection{What Is Digital Business?}

SMEs are arguably the backbone of the economy in many countries and often represent a catalyst for economic growth. This is particularly the case in rural communities where rural enterprises provide a key contribution to local economic and social resilience, and influence the life of rural communities in both direct and indirect ways (Eachus, 2014; Steiner \& 
Atterton, 2015). Direct effects include more obvious benefits such as the creation of local employment and local product/service availability (Eachus, 2014). Indirect effects are somewhat less visible and yet extremely beneficial for rural communities (Bruce et al., 2006). These include, for example, a reduced risk of migration toward urban areas thanks to local employment opportunities and the development of a more active and higher value local economy that leads to higher quality of life (Hegney et al., 2008).

Unsurprisingly, SME support and rural development are constant items on the agenda of policy makers (Bennett, 2008; Mole et al., 201 1; Skerratt \& Steiner, 2013; Lyee \& Cowling, 2015) however the level of sophistication and effectiveness of such interventions varies depending on their geographical location (European Commission, 2019; Phillipson et al., 2019). In fact, the evidence suggests that despite rural SMEs being comparable to (if not better than) their urban counterparts in terms of longevity, exports and economic growth, they receive significantly less attention and support than urban SMEs (Phillipson et al., 2019).

Some of the challenges affecting rural enterprises may be similar to those faced by urban SMEs but others are typical of rural environments. These challenges can be summarised in the following five categories (Interreg Europe, 2020):

1. Digital infrastructure: rural communities typically lag urban areas in terms of connectivity and this may lead to a digital divide between urban SMEs and rural SMEs in terms of the adoption of digital technologies (Richmond et al., 2017).

2. Access to finance: while access to finance is a known challenge for SMEs due to their limited collateral, this issue is particularly accentuated in rural areas where there is a general shortage of alternatives to bank financing. In fact, investors tend to focus on high-growth SMEs / start-ups which are typically located in urban areas. The vast majority of enterprises in rural areas are small with no, low or average growth rates. These are less attractive for investors but at the same time contribute significantly to regional and national growth (Freshwater et al., 2019).

3. Skills: skilled talent tends to be clustered around universities which are typically located in urban areas. Therefore, it is significantly harder for rural SMEs to attract skilled individuals and this ultimately may nega- 
tively impact the ability of rural enterprises to innovate and grow (Phillipson et al., 2019).

4. Seasonal challenges: rural SMEs are typically less diversified in their economic activities therefore seasonal changes such as an inconsistent influx of seasonal customers/workers throughout the year may make it more difficult for local businesses to grow.

5. Access to new markets: rural enterprises rely on external markets to grow due to the limited size of their local markets. Entering new markets though can be particularly challenging for rural enterprises due to geographical and/or infrastructural barriers.

The roll out of connectivity infrastructure in rural areas is mostly being driven by national governments (Salemink et al., 2017). However, merely providing the infrastructure is not sufficient to make an impact. Adoption and actual usage are the next steps that need to be taken for digital connectivity to have an impact on rural communities in general and businesses in particular (Hage et al., 2013). The adoption of digital technologies could mitigate all the other challenges presented above by facilitating entry into new markets, providing access to training and skills, and ultimately by enabling growth (Price et al., 2018).

The adoption of infrastructure for digital connectivity is also a necessary prerequisite for enabling digital business practices in rural enterprises. Digital business is a relatively new concept and in the academic literature it is often referred to as e-business or electronic commerce. A number of different definitions of e-business have been proposed over time and are presented in Table 4.2.

Most definitions link digital business to the use of Internet technologies or mobile technologies, while others (e.g., Rayport \& Jaworski, 2001) provide a technology-agnostic definition of e-business. A common trait across these definitions is the transactional nature of e-business. However, digital business is much broader than transaction-based commerce conducted via digital means (Chaffey et al., 2019). Chaffey et al. (2019, p. 15) define digital business as "how businesses apply digital technology and media to improve the competitiveness of their organisation through optimising internal processes with online and traditional channels to market and supply". As such, digital business is not only limited to buying and selling online but it encompasses a range of processes and activities enabled by digital technologies that aim to integrate the digital and physical worlds (Gartner, 2021). 
Table 4.2 Selected definitions of e-business (adapted from Wirtz, 2019)

\begin{tabular}{ll}
\hline Definition & Source \\
\hline $\begin{array}{l}\text { Technology-mediated exchanges between parties (individuals, } \\
\text { organisations, or both) as well as the electronical based intra- or }\end{array}$ & $\begin{array}{l}\text { Rayport and } \\
\text { Jaworski (2001) }\end{array}$ \\
inter-organisational activities that facilitate such exchange. & \\
The use of electronic means to conduct an organisation's business & Jelassi and \\
internally and/or externally. & Enders (2005) \\
$\begin{array}{l}\text { Business that is conducted using electronic networks or electronic } \\
\text { media. Sometimes used synonymously with e-commerce and }\end{array}$ & Chen (2005) \\
$\begin{array}{l}\text { sometimes used more widely to include other business activities in } \\
\text { addition to buying and selling. }\end{array}$ & \\
$\begin{array}{l}\text { The conduct of automated business transactions by means of electronic } \\
\text { communications networks (e.g., via the internet and/or possibly } \\
\text { private networks) end-to-end. }\end{array}$ & $\begin{array}{l}\text { Pibbers (2006) } \\
\text { All electronically mediated information exchanges, both within an } \\
\text { organisation and with external stakeholders supporting the range of } \\
\text { business processes. }\end{array}$ \\
$\begin{array}{l}\text { The use of internet, the world wide web (web) and mobile Apps to } \\
\text { transact business. }\end{array}$ & $\begin{array}{l}\text { Chaffey (2007) } \\
\text { All business activities that use internet technologies. Internet } \\
\text { technologies include the internet, the world wide web and other } \\
\text { technologies such as wireless transmissions on mobile telephone } \\
\text { networks. }\end{array}$ \\
\hline
\end{tabular}

Digital business definitions rarely distinguish between mainstream and frontier technologies, however by and large they focus on the former. Frontier technologies represent a significant opportunity for businesses with some market estimates as high as US\$3.2 trillion by 2025 (UNCTAD, 2021 ). The adoption of such technologies is not uniform. For example, the finance and manufacturing sectors were early adopters of AI, IoT, big data and blockchain, and the US and China dominate frontier technology supply (UNCTAD, 2021). While the opportunity for frontier technologies for economies is significant in terms of jobs and expenditure, capacity to exploit these technologies depends heavily on human capital, access to finance, and other structural factors to support scale (UNCTAD, 2021). Unfortunately, these are less likely to be found in rural communities (UNCTAD, 2021).

Finally, it must be noted that some commentators suggest that it is important to differentiate between (1) businesses that make extensive use 
of digital technologies (their existence depends on digital technologies), and (2) businesses that make intensive use of digital technologies (applying digital technology to enhance their productivity) (Bukht \& Heeks, 2017). Consequently, one can conceptualise the adoption and use of digital technologies across a spectrum of competencies, from core and distinctive to common and subordinate as per Fig. 4.1.

\subsection{Benefits and Challenges of Digital Technologies for Businesses}

Digital business leverages a wide range of digital technologies including website technologies, digital advertising, social media and social commerce, email marketing, mobile and e-commerce, and analytics, amongst others. The emergence of cloud computing in particular provides SMEs with the opportunity to outsource their technology infrastructure to support their web operations therefore providing greater reliability and scalability (Trigueros-Preciado et al., 2013; Leimbach et al., 2014). Similarly, the availability of user-friendly digital advertising platforms and content management systems (CMS) with support for mobile responsive themes has resulted in websites that are easy to navigate on both desktop and mobile devices therefore providing users with a more seamless experience. These technologies can support a range of commercial objectives including information dissemination and exchange (Daniel et al., 2002; Jeansson et al., 2017), demand generation (Jones et al., 2015; Richmond et al., 2017), sales (Drew, 2003; Jones et al., 2015; Jeansson et al., 2017; Tiwasing, 2021), and customer relationship management (McCann \& Barlow, 2015; Richmond et al., 2017).

The potential benefits of digital technologies to SMEs are wellestablished. These include, reductions in distance-related barriers (Walczuch et al., 2000; Sinkovics \& Sinkovics, 2013), cost savings and operational efficiency (Walczuch et al., 2000; Trigueros-Preciado et al., 2013), IT resilience and scalability (Trigueros-Preciado et al., 2013; Leimbach et al., 2014), easier access to new markets (Walczuch et al., 2000; Jones et al., 2003; Pergelova et al., 2019), marketing effectiveness (Jones et al., 2015), customer service and engagement (Claffey \& Brady, 2014), and market and customer intelligence (Tiago \& Verissimo, 2014). From a strategic perspective, digital technologies can represent the basis for a competitive advantage for SMEs and enable them to compete with 
larger firms (Mehrtens et al., 2001; Richmond et al., 2017). Despite the wide range of benefits provided by digital technologies, SMEs continue to lag in terms of adoption and usage when compared to their larger counterparts, particularly with regard to the adoption of more sophisticated technologies (OECD, 2021). This is due to a number of reasons including difficulty accessing skills and skilled resources, perceived risk associated with greater investment to adopt and support more advanced technologies (McDowell et al., 2016), or security (Trigueros-Preciado et al., 2013; Leimbach et al., 2014).

The digital divide between urban and rural communities has been a focus of research for a number of years (Hindman, 2000; Townsend et al., 2013; Philip et al., 2017; OECD, 2021). However, the divide between urban and rural SMEs in general and micro-enterprises in particular has not attracted the same level of interest from researchers. Previous studies reported relatively low broadband access, website and social media use by rural SMEs in developed countries (Michaelidou et al., 2011; Daun \& Muessig, 2012; Townsend et al., 2013). More recently, Richmond et al. (2017) found that, while broadband access has become more widespread in rural communities, rural SMEs still lagged urban SMEs in online marketing practices, website sophistication, and e-commerce and social media usage.

The need for more widespread adoption of digital technologies by rural SMEs has become even more evident since the breakout of the COVID-19 pandemic and the associated disruption of the normal operations of businesses worldwide. In fact, SMEs have been disproportionately impacted by the restrictions put in place by national governments in order to contain the spread of the virus (OECD, 2021). This is because SMEs (1) are over-represented in sectors that have been impacted by lockdowns, (2) have lower productivity and weaker supply chain capabilities, (3) are more fragile than large firms from a financial perspective due to limited cash reserves, and (4) typically lack the managerial capabilities to navigate through the evolving challenges presented by the pandemic (Bartik et al., 2020; Cowling et al., 2020; Humphries et al., 2020; OECD, 2021). Despite the large number of initiatives launched by different governments to promote and support digitalisation, innovation and technology development, upskilling and reskilling, and finding new alternative markets for SMEs (OECD, 2021), a large number of SMEs reported making significant layoffs during the COVID-19 pandemic, and expect that it could take up to two years for them to recover (Bartik et al., 2020; Humphries 
et al., 2020). Rural SMEs are likely to be more adversely affected due to their less diversified economic activity, disproportionate reliance on local markets, disruption to national and international supply chains and, as mentioned above, their lower adoption and use of digital technologies (Richmond et al., 2017; OECD, 2020).

Against the backdrop of COVID-19, the pandemic has contributed to a significant acceleration of digital initiatives and may lead to a radical change in consumer behaviour (Guo et al., 2020; McKinsey, 2020; Riom \& Valero, 2020). Such a change may represent an opportunity for businesses (Klein \& Todesco, 2021) so it is crucial for rural SMEs to be fully equipped to fully seize this opportunity.

\subsection{Measuring Digital Business}

As is evident from Chap. 1, there is a large number of measurement frameworks and composite indices for measuring digital business, typically labelled under the 'Digital Economy'. Not only do these include frameworks specific to the digital economy but those seeking to measure the evolution and development of the Digital Society e.g., DESI (Digital Economy and Skills Unit, 2020). The proliferation of these frameworks is largely due to the priority given to economic research and the availability of data at a national level.

There are a wide range of digital economy indicators included in extant frameworks and composite indices. These can be categorised into a number of major themes as per Table 4.2; links to sources and indicators can be found in the Useful Resources section at the end of the book. The majority of the indicators that compose digital economy indices are sourced from national sources and statistics and are aggregated by a variety of sources for international comparison as indicated in Table 4.3. Data for a specific rural town and environs may not be available at a national level depending on the methodology employed for data collection. Furthermore and as discussed in Chap. 1, such statistics may only include enterprises with more than ten employees. As a result, micro-enterprises, that make up the bulk of rural SMEs, may not be included. Furthermore, extant measures typically do not include new paradigms and business models enabled by digital technologies such as the so-called 'sharing economy' and 'gig economy'. Measuring these activities is more difficult as traditional sources of national statistics may not probe sufficiently to uncover such work arrangements, workers may not consider these 
Table 4.3 Common themes and selected international sources for digital business

\begin{tabular}{|c|c|c|}
\hline Themes & Description & $\begin{array}{l}\text { Selected international benchmark data } \\
\text { sources }\end{array}$ \\
\hline Access & $\begin{array}{l}\text { Availability and access to } \\
\text { digital technologies (incl. } \\
\text { The internet) by workers } \\
\text { where work occurs } \\
\text { including home working. }\end{array}$ & $\begin{array}{l}\text { EU Broadband Coverage in Europe } \\
\text { Studies; EU Broadband Internet Access } \\
\text { (BIAC) surveys; EU Communications } \\
\text { Committee surveys; Eurostat, ITU World } \\
\text { Telecommunication/ICT Indicators } \\
\text { database; OECD Broadband portal; } \\
\text { UNESCO Institute for Statistics }\end{array}$ \\
\hline $\begin{array}{l}\text { Digital } \\
\text { competence, } \\
\text { self-efficacy and } \\
\text { skills of } \\
\text { workforce }\end{array}$ & $\begin{array}{l}\text { Workforce competence, } \\
\text { self-efficacy and skills } \\
\text { using different } \\
\text { technologies and } \\
\text { performing related tasks. } \\
\text { Enrolment and graduates } \\
\text { from ICT-related courses } \\
\text { or fields. }\end{array}$ & $\begin{array}{l}\text { Eurostat, EU Survey of Schools: ICT in } \\
\text { Education, PISA, UNESCO Institute for } \\
\text { Statistics, ILO Labour Force Surveys }\end{array}$ \\
\hline Employment & $\begin{array}{l}\text { Employment in the ICT } \\
\text { sector and ICT } \\
\text { occupations. }\end{array}$ & $\begin{array}{l}\text { Eurostat, ILO Labour Force Surveys; } \\
\text { OECD Structural Analysis (STAN) } \\
\text { Database }\end{array}$ \\
\hline Equity & $\begin{array}{l}\text { Relative proportion of } \\
\text { female employees in the } \\
\text { ICT sector and in ICT } \\
\text { occupations, and female } \\
\text { ICT graduates in } \\
\text { ICT-related fields. }\end{array}$ & $\begin{array}{l}\text { Eurostat; ILO Labour Force Surveys, } \\
\text { OECD Education database, UNESCO } \\
\text { Institute for Statistics }\end{array}$ \\
\hline Growth & $\begin{array}{l}\text { Value added by } \\
\text { information industries and } \\
\text { digitally-intensive } \\
\text { industries; ICT } \\
\text { investment; ICT } \\
\text { productivity growth; ICT } \\
\text { and global value chains, } \\
\text { ICT and digital deliverable } \\
\text { services as a proportion of } \\
\text { trade. }\end{array}$ & $\begin{array}{l}\text { Eurostat; OECD Inter-Country Input- } \\
\text { Output (ICIO) tables; OECD Trade in } \\
\text { Value Added (TiVA) database; OECD } \\
\text { Productivity Statistics database; UNCTAD } \\
\text { Digital Economy database }\end{array}$ \\
\hline
\end{tabular}


Table 4.3 (continued)

\begin{tabular}{|c|c|c|}
\hline Themes & Description & $\begin{array}{l}\text { Selected international benchmark data } \\
\text { sources }\end{array}$ \\
\hline $\begin{array}{l}\text { Innovation \& } \\
\text { Technology }\end{array}$ & $\begin{array}{l}\text { R\&D in digital } \\
\text { technologies; Government } \\
\text { funding of business R\&D } \\
\text { and tax incentives for } \\
\text { ICT-related R\&D; Patents } \\
\text { and trademarks granted } \\
\text { for ICT-related products } \\
\text { and services. }\end{array}$ & $\begin{array}{l}\text { JRC-IPTS Reports on Public ICT R\&D } \\
\text { Expenditures; OECD Intellectual Property } \\
\text { Database, OECD Main Science and } \\
\text { Technology Indicators (MSTI) Database, } \\
\text { OECD Analytical Business Enterprise } \\
\text { Research and Development (ANBERD) } \\
\text { database; OECD R\&D Tax Incentives } \\
\text { database; OECD Structural Analysis } \\
\text { (STAN) Database }\end{array}$ \\
\hline Use & $\begin{array}{l}\text { Incidence, intensity and } \\
\text { patterns of digital } \\
\text { technology use by } \\
\text { businesses and employees } \\
\text { for selected technologies, } \\
\text { to conduct business across } \\
\text { borders, and to interact } \\
\text { with public authorities. }\end{array}$ & $\begin{array}{l}\text { Eurostat; ITU World Telecommunication/ } \\
\text { ICT Indicators database; OECD } \\
\text { Broadband portal }\end{array}$ \\
\hline
\end{tabular}

activities as their primary employment or even a job, or workers may not wish to report such activities for tax avoidance reasons (Riggs et al., 2019). Similarly, statistics based on the digital platforms that enable these activities may not be comprehensive, representative, or consistent over time (Riggs et al., 2019). Most international frameworks do not include evaluations of laws and regulations related to digital business, one would assume due to the difficulty in reducing these variables to a numeric indicator. That is not to say that such indicators do not exist. The World Bank Digital Business Indicators (Chen, 2019) includes indicators for data privacy and security (individual rights, cross-border data flows, and data security and enforcement) and digital market regulations (consumer protection, intermediary liability, and e-signatures). Similarly, Chakravorti et al. (2019) include a measurement of institutional barriers (wholesale foreign direct investment (FDI) regulatory restrictiveness indicator, anti-monopoly policy, and FDI regulations). In the context of rural towns, these are less important measurements in that local decision-makers do not typically have the requisite agency to effect change in laws and regulations.

Despite the wide range of indicators included in these frameworks, the extent to which they assess the penetration and the use of a comprehensive 
and relevant range of technologies by businesses is limited. There are exceptions. DESI, the G20 Digital Economy Task Force, and the Partnership on Measuring ICT for Development all propose indicators using ICTs other than internet infrastructure and computer equipment (see Table 4.4), some of which can be inferred by activities reported. Furthermore, data on other relevant indicators may be collected but not used in these frameworks. For example, Eurostat's Digital Economy and Society Statistics includes data on computer-based tasks performed by individuals at work including e-mail, data entry, electronic document creation or editing, received tasks via apps, occupation-specific software, social media use for work purposes, and developed or maintained IT systems or software (Eurostat, 2021). This data can be used to infer digital technologies used by businesses.

\subsection{Conclusion}

The potential benefits of digital business technologies adoption for enterprises including SMEs are well established, and yet adoption and use by rural enterprises still lag their urban counterparts, particularly for more advanced technologies and sophisticated uses. This is an important differentiation as it is through leveraging emerging technologies that the

Table 4.4 Selected indicators for digital business in digital society and digital economy measurement frameworks and composite indices

\begin{tabular}{|c|c|c|}
\hline Framework & Description & Source \\
\hline $\begin{array}{l}\text { Digital Economy \& } \\
\text { Society Index (DESI) }\end{array}$ & $\begin{array}{l}\text { - } \text { Electronic Information Sharing } \\
\text { - } \text { RFID } \\
\text { - } \text { Social Media } \\
\text { - } \text { eInvoices } \\
\text { - } \text { SMeud computing } \\
\text { - } \text { E-commerce Turnover } \\
\text { - Selling Online Cross-border }\end{array}$ & $\begin{array}{l}\text { Digital Economy } \\
\text { and Skills Unit } \\
(2020)\end{array}$ \\
\hline $\begin{array}{l}\text { G20 Toolkit for } \\
\text { Measuring the Digital } \\
\text { Economy }\end{array}$ & $\begin{array}{l}\text { - Infrastructure for the Internet of } \\
\text { Things using GSMA data } \\
\text { - Secure server infrastructure } \\
\text { - Sales via e-commerce } \\
\text { - ICT goods as percentage of } \\
\text { merchandise trade } \\
\text { - ICT services as percentage of services } \\
\text { trade }\end{array}$ & $\begin{array}{l}\text { G20 Digital } \\
\text { Economy Task } \\
\text { Force }(2018)\end{array}$ \\
\hline
\end{tabular}


Table 4.4 (continued)

\begin{tabular}{|c|c|c|}
\hline Framework & Description & Source \\
\hline $\begin{array}{l}\text { Partnership on } \\
\text { Measuring ICT for } \\
\text { Development }\end{array}$ & $\begin{array}{l}\text { - } \text { Computers } \\
\text { - Internet } \\
\text { - } \text { Beb presence } \\
\text { - Intranet, extranet or local area network } \\
\text { - Giving or receiving orders over the } \\
\text { - Internet } \\
\text { - } \text { Tending or receiving email } \\
\text { - } \text { voice over Internet Protocol), or } \\
\text { - Using video-conferencing } \\
\text { - } \text { boards instant messaging, bulletin } \\
\text { - } \text { services } \\
\text { - } \text { getting information from general } \\
\text { - Interacting with general government } \\
\text { - Internet banking } \\
\text { - Accessing other financial services } \\
\text { - Intivering products online } \\
\text { - Staff training }\end{array}$ & ITU (2018) \\
\hline
\end{tabular}

greatest benefits and opportunities may be realised. While policymakers have been mostly focused on connectivity, there are also a number of other reasons behind this digital divide that have partly been overlooked. These include, for example, limited access to finance and skilled resources that put rural enterprises in a disadvantaged position compared to urban enterprises, largely due to their size and location. There are a number of initiatives that aim to measure the level of adoption and sophistication of digital business technologies by SMEs but they tend to leverage secondary data that are only available at a national or regional level. These assessments are typically based on samples where rural SMEs and micro-enterprises are under-represented compared to urban SMEs due to information availability and ease of access. As such, any decision taken on the basis of aggregated statistics may ultimately widen the urban-rural divide even further. 


\section{REFERENCES}

Bartik, A. W., Bertrand, M., Cullen, Z. B., Glaeser, E. L., Luca, M., \& Stanton, C. T. (2020). How are small businesses adjusting to COVID-19? Early evidence from a survey (No. w26989). National Bureau of Economic Research.

Bennett, R. (2008). SME policy support in Britain since the 1990s: What have we learnt? Environment and Planning C: Government and Policy, 26(2), 375-397.

Bruce, D. W., Ellis, K., \& Delury, N. (2006). The role and impact of community newsletters in fostering social cohesion and community development. Journal of Rural and Community Development, 1(2), 151816825.

Brynjolfsson, E., \& Kahin, B. (2000). Introduction. In E. Brynjolfsson \& B. Kahin (Eds.), Understanding the digital economy (pp. 1-10). MIT Press.

Bukht, R., \& Heeks, R. (2017). Defining, conceptualising and measuring the digital economy. Development Informatics Working Paper (68).

Chaffey, D. (2007). E-business and e-commerce management: Strategy, implementation and practice. Pearson Education.

Chaffey, D., Edmundson-Bird, D., \& Hemphill, T. (2019). Digital business and e-commerce management. Pearson UK.

Chakravorti, B., Fillpovic, C., \& Chaturvedi, R. S. (2019). Ease of doing digital business 2019. Which countries help expedite entry, growth, and exit of technology-based businesses. Institute for Business in the global context. The fletcher school, tufts university. URL: https://sites.tufts.edu/digitalplanet/ research/ease-of-doing-digitalbusiness.

Chen, S. (2005). Strategic management of e-business. John Wiley \& Sons, Inc.

Chen, R. (2019). Policy and regulatory issues with digital businesses. World Bank Policy Research Working Paper (8948).

Claffey, E., \& Brady, M. (2014). A model of consumer engagement in a virtual customer environment. Journal of Customer Behaviour, 13(4), 325-346.

Cowling, M., Brown, R., \& Rocha, A. (2020). Did you save some cash for a rainy COVID-19 day? The crisis and SMEs. International Small Business Journal, 38(7), 593-604.

Dahlman, C., Mealy, S., \& Wermelinger, M. (2016). Harnessing the digital economy for developing countries. OECD. https://www.oecd-ilibrary.org/ docserver $/ 4$ adffb24-en.pdf?expires=1629534032 \&id=id\&accname=guest\&c hecksum $=54$ A9417FF79202F06C11B8B8B9A6C10C

Daniel, E., Wilson, H., \& Myers, A. (2002). Adoption of e-commerce by SMEs in the UK: towards a stage model. International Small Business Journal, 20(3), 253-270.

Department of Broadband, Communications and the Digital Economy (DBCDE). (2013). Advancing Australia as a digital economy: An update to the national digital economy strategy. https://apo.org.au/sites/default/files/resourcefiles/2013-06/apo-nid34523.pdf 
Digital Economy and Skills Unit. (2020). The Digital Economy and Society Index 2020-Methodological note. https://digital-strategy.ec.europa.eu/en/policies/desi Drew, S. (2003). Strategic uses of e-commerce by SMEs in the east of England. European Management Journal, 21(1), 79-88.

Daun, T. R., \& Muessig, H. (2012). Assessing the digital presence of rural Minnesota businesses: Basic methods \& findings. In M. Vitcenda (Ed.), Technical report, extension center for community vitality. St. Paul, MN: University of Minnesota.

Eachus, P. (2014). Community resilience: Is it greater than the sum of the parts of individual resilience? Procedia economics and Finance, 18, 345-351.

Interreg Europe. (2020). How to boost entrepreneurship in rural areas? https:// www.interregeurope.eu/fileadmin/user_upload/tx_tevprojects/library/ file_1588771652.pdf

European Commission. (2013). Expert group on taxation of the digital economy-General issues. https://ec.europa.eu/taxation_customs/system/ files/2016-09/general_issues.pdf

European Commission. (2019). EU policy framework on SMEs: state of play and challenges. https://cor.europa.eu/en/engage/studies/Documents/EUSMEs/EU-policy-SMEs.pdf

Eurostat. (2021). Digital economy and society-Overview. https://ec.europa. eu/eurostat/web/digital-economy-and-society

Freshwater, D. (2018). Fostering growth in less favoured regions: Adapting the concept of smart specialization to rural economic development. In Strategic approaches to regional development (pp. 39-57). Routledge.

Freshwater, D., Garcilazo, E., Latto, J., Pace, J., Simms, A., Ward, J., \& Wojan, T. (2019). Business development and the growth of rural SMEs (No. 2019/07). OECD Publishing.

G20 Digital Economy Task Force (DETF). (2016). G20 Digital economy development and cooperation initiative. http://www.g20.utoronto.ca/2016/g20digital-economy-development-and-cooperation.pdf.

G20 Digital Economy Task Force (DETF). (2018). G20 toolkit for measuring the digital economy. OECD. https://www.oecd.org/g20/summits/buenosaires/G20-Toolkit-for-measuring-digital-economy.pdf

G20 Digital Economy Task Force (DETF). (2020). A roadmap toward a common framework for measuring the digital economy. OECD.

Gartner. (2021). Gartner glossary-Digital business. https://www.gartner.com/ en/information-technology/glossary/digital-business

Guo, H., Yang, Z., Huang, R., \& Guo, A. (2020). The digitalization and public crisis responses of small and medium enterprises: Implications from a COVID-19 survey. Frontiers of Business Research in China, 14(1), 1-25. 
Hage, E., Roo, J. P., van Offenbeek, M. A., \& Boonstra, A. (2013). Implementation factors and their effect on e-Health service adoption in rural communities: a systematic literature review. BMC Health Services Research, 13(1), 1-16.

Hegney, D., Ross, H., \& Baker, P. (2008). Building resilience in rural communities: Toolkit.

Hindman, D. B. (2000). The rural-urban digital divide. Journalism \& Mass Communication Quarterly, 77(3), 549-560.

House of Commons. (2016). The digital economy. House of Commons Business, Innovation and Skills Committee. https://publications.parliament.uk/pa/ $\mathrm{cm} 201617 / \mathrm{cmselect} / \mathrm{cmbis} / 87 / 87 . \mathrm{pdf}$

Humphries, J. E., Neilson, C., \& Ulyssea, G. (2020). The evolving impacts of COVID-19 on small businesses since the CARES Act. Cowles Foundation Discussion Paper.

ITU. (2018). Measuring the information society report 2018. ITU Publications.

Jeansson, J., Nikou, S., Lundqvist, S., Marcusson, L., Sell, A., \& Walden, P. (2017). SMEs' online channel expansion: Value creating activities. Electronic Markets, 27(1), 49-66.

Jelassi, T., \& Enders, A. (2005). Strategies for e-business: Creating value through electronic and mobile commerce: Concepts and cases. Pearson Education.

Jones, P., Beynon-Davies, P., \& Muir, E. (2003). E-business barriers to growth within the SME sector. Journal of Systems and Information Technology, $7(1), 1-26$.

Jones, N., Borgman, R., \& Ulusoy, E. (2015). Impact of social media on small businesses. Journal of Small Business and Enterprise Development, 22(4), 611-632.

Klein, V. B., \& Todesco, J. L. (2021). COVID-19 crisis and SMEs responses: The role of digital transformation. Knowledge and Process Management, 28(2), 117-133.

Kling, R., \& Lamb, R. (2000). IT and organizational change in digital economies. In E. Brynjolfsson \& B. Kahin (Eds.), Understanding the digital economy (pp. 295-324). MIT Press.

Knickrehm, M., Berthon, B., \& Daugherty, P. (2016). Digital disruption: The growth multiplier. Accenture. https://www.oxfordeconomics.com/recentreleases/digital-disruption

Laudon, K. C., \& Traver, C. G. (2013). E-commerce. Pearson.

Leimbach, T., Hallinan, D., Bachlechner, D., Weber, A., Jaglo, M., Hennen, L., ... Hunt, G. (2014). Potential and impacts of cloud computing services and social network websites. Publication of Science and Technology Options Assessment.

Liu, S. (2021). The urban-rural divide: The effects of the small business innovation research program in small and nonmetro counties. Economic Development Quarterly, 08912424211029709. 
Lyee, N., \& Cowling, M. (2015). Do rural firms perceive different problems? Geography, sorting, and barriers to growth in UK SMEs. Environment and Planning C: Government and Policy, 33(1), 25-42.

McCann, M., \& Barlow, A. (2015). Use and measurement of social media for SMEs. Journal of Small Business and Enterprise Development.

McDowell, W. C., Wilson, R. C., \& Kile, C. O., Jr. (2016). An examination of retail website design and conversion rate. Journal of Business Research, 69(11), $4837-4842$.

McKinsey. (2020). How COVID-19 has pushed companies over the technology tipping point-And transformed business forever. https://www.mckinsey. $\mathrm{com} /$ business-functions/strategy-and-corporate-finance/our-insights/ how-covid-19-has-pushed-companies-over-the-technology-tipping-point-andtransformed-business-forever

Mehrtens, J., Cragg, P. B., \& Mills, A. M. (2001). A model of internet adoption by SMEs. Information \& Management, 39(3), 165-176.

Michaelidou, N., Siamagka, N. T., \& Christodoulides, G. (2011). Usage, barriers and measurement of social media marketing: An exploratory investigation of small and medium B2B brands. Industrial Marketing Management, 40(7), 1153-1159.

Mole, K. F., Hart, M., Roper, S., \& Saal, D. S. (2011). Broader or deeper? Exploring the most effective intervention profile for public small business support. Environment and Planning A, 43(1), 87-105.

OECD. (2013). The digital economy. https://www.oecd.org/daf/competition/ The-Digital-Economy-2012.pdf

OECD. (2014). Innovation and modernising the rural economy. https://read. oecd-ilibrary.org/urban-rural-and-regional-development/innovation-andmodernising-the-rural-economy_9789264205390-en\#page1

OECD. (2020). Policy implications of coronavirus crisis for rural development. https://read.oecd-ilibrary.org/view/?ref=134_134479-8kq0i6epcq\&title=Po licy-Implications-of-Coronavirus-Crisis-for-Rural-Development\&_ $\mathrm{ga}=2.224691993 .2086061152 .1627638484-1523894854.1627638484$

OECD. (2021). The digital transformation of SMEs. https://www.oecd-ilibrary. org/industry-and-services/the-digital-transformation-of-smes_bdb9256a-en

Papazoglou, M. P., \& Ribbes, P. M. A. (2006). E-business: Organizational and technical foundations. John Wiley and Sons.

Pergelova, A., Manolova, T., Simeonova-Ganeva, R., \& Yordanova, D. (2019). Democratizing entrepreneurship? Digital technologies and the internationalization of female-led SMEs. Journal of Small Business Management, 57(1), 14-39.

Philip, L., Cottrill, C., Farrington, J., Williams, F., \& Ashmore, F. (2017). The digital divide: Patterns, policy and scenarios for connecting the 'final few' in rural communities across Great Britain. Journal of Rural Studies, 54, 386-398. 
Phillipson, J., Tiwasing, P., Gorton, M., Maioli, S., Newbery, R., \& Turner, R. (2019). Shining a spotlight on small rural businesses: How does their performance compare with urban? Journal of Rural Studies, 68, 230-239.

Pratt, M. K. (2017). Digital economy. TechTarget. https://searchcio.techtarget. com/definition/digital-economy

Price, L., Shutt, J., \& Sellick, J. (2018). Supporting rural small and medium-sized enterprises to take up broadband-enabled technology: What works? Local Economy, 33(5), 515-536.

Rayport, J. F., \& Jaworski, B. J. (2001). E-commerce. McGraw-Hill.

Richmond, W., Rader, S., \& Lanier, C. (2017). The 'digital divide' for rural small businesses. Journal of Research in Marketing and Entrepreneurship, 19(2), 94-104.

Riggs, L., Sin, I., \& Hyslop, D. (2019). Measuring the 'gig' economy: Challenges and options. Available at SSRN 3492834.

Riom, C., \& Valero, A. (2020). The business response to Covid-19: The CEP-CBI survey on technology adoption. Centre for Economic Performance, London School of Economics and Political Science.

Salemink, K., Strijker, D., \& Bosworth, G. (2017). Rural development in the digital age: A systematic literature review on unequal ICT availability, adoption, and use in rural areas. Journal of Rural Studies, 54, 360-371.

Schneider, G.P. (2017). Electronic Commerce. Australia: Cengage Learning.

Sinkovics, N., Sinkovics, R.R. and "Bryan" Jean, R. (2013), "The internet as an alternative path to internationalization?", International Marketing Review, $30(2), 130-155$.

Skerratt, S., \& Steiner, A. (2013). Working with communities-of-place: Complexities of empowerment. Local Economy, 28(3), 320-338.

Steiner, A., \& Atterton, J. (2015). Exploring the contribution of rural enterprises to local resilience. Journal of Rural Studies, 40, 30-45.

Sturgeon, T. J. (2021). Upgrading strategies for the digital economy. Global Strategy Journal, 11(1), 34-57.

Tiago, M. T. P. M. B., \& Verissimo, J. M. C. (2014). Digital marketing and social media: Why bother? Business Horizons, 57(6), 703-708.

Tiwasing, P. (2021). Social media business networks and SME performance: A rural-urban comparative analysis. Growth and Change, 52(3), 1892-1913.

Townsend, L., Sathiaseelan, A., Fairhurst, G., \& Wallace, C. (2013). Enhanced broadband access as a solution to the social and economic problems of the rural digital divide. Local Economy, 28(6), 580-595.

Trigueros-Preciado, S., Pérez-González, D., \& Solana-González, P. (2013). Cloud computing in industrial SMEs: Identification of the barriers to its adoption and effects of its application. Electronic Markets, 23(2), 105-114.

UNCTAD. (2021). Technology and innovation report 2021. United Nations Publications. 
Walczuch, R., Van Braven, G., \& Lundgren, H. (2000). Internet adoption barriers for small firms in the Netherlands. European Management Journal, $18(5), 561-572$.

Wirtz, B. W. (2019). Digital business models: Concepts, models, and the alphabet case study. Springer.

World Bank. (2021). Small and Medium Enterprises (SMEs) Finance. https:// www.worldbank.org/en/topic/smefinance

World Economic Forum (WEF). (2015). Expanding participation and boosting growth: The infrastructure needs of the digital economy. http://www3.weforum.org/docs/WEFUSA_DigitalInfrastructure_Report2015.pdf

Open Access This chapter is licensed under the terms of the Creative Commons Attribution 4.0 International License (http://creativecommons.org/licenses/ by $/ 4.0 /$ ), which permits use, sharing, adaptation, distribution and reproduction in any medium or format, as long as you give appropriate credit to the original author(s) and the source, provide a link to the Creative Commons licence and indicate if changes were made.

The images or other third party material in this chapter are included in the chapter's Creative Commons licence, unless indicated otherwise in a credit line to the material. If material is not included in the chapter's Creative Commons licence and your intended use is not permitted by statutory regulation or exceeds the permitted use, you will need to obtain permission directly from the copyright holder.

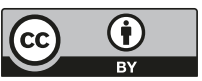

